\title{
In Search of Insight: The Value of APSA's Congressional Fellowship Program in Times Like These
}

\author{
Stephen Dietz, APSA Congressional Fellow, 2015-2016
}

All views and opinions expressed in this article are those of the author.

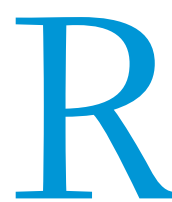

oughly three years ago, a little after dawn, I sat blearyeyed in a frigid conference room in sweltering Bali, Indonesia, as the representatives of 160-odd member countries of the World Trade Organization (WTO) concluded a trade deal worth over US\$1 trillion. The night before had been a long and turbulent one-full of false starts, rumors of collapse (any country could veto the deal, and many threatened to) and last-minute compromises. Nevertheless, with the arrival of the sun, the WTO defied its many critics-and most of its supporters-by achieving what it had eluded it for more than a decade: a major global trade deal.

After the fact, in discussing the milestone with my colleagues, the most common reaction was surprise. Most thought that the WTO was a dysfunctional and decaying institution, incapable of achieving much at all. I understood the skepticism but didn't share it. From what I had seen, if you pulled the right levers and played your cards right, you could achieve tangible progress there. I found myself wishing that my colleagues had had the opportunity to spend a little time inside the WTO, to get to know its inner workings and its foibles, and to take that knowledge with them as they tried to solve the world's problems in their diplomatic careers.

You might rightfully ask what this has to do with APSA's Congressional Fellowship Program (CFP). The answer is somewhat harsh: that the WTO and Congress share similarly ignominious reputations as dysfunctional arenas in which titans clash (be they nations or elected representatives), but precious little is accomplished. The public is surprised when either institution achieves a significant outcome.

Of course, the reality for Congress, just as for the WTO, is far more complicated. Sure, the modus operandi is byzantine and unreliable, and virtually inscrutable from the outside, but things get done. The CFP is the vehicle I wished existed for the WTO, affording to those who teach, engage with, or aspire to work in Congress an opportunity to gain perspective that is personally enriching, professionally useful, and societally valuable.

I was motivated to join the CFP partly by curiosity-few foreigners have the opportunity to see inside the monolithic institution-and partly for my profession. Events leading up to the Bali summit taught me that Congress, in exercising its power to approve or disapprove

Stephen Dietz served as the 2015-2016 American Australian Association / APSA Congressional Fellow in the office of Senator Bob Casey (D-PA). He is on leave from the Australian Department of Foreign Affairs and Trade, where he worked as a diplomatic officer since 2009, primarily on international trade negotiations and disputes. A General Sir John Monash Scholar, Stephen is completing a Master of Laws at Columbia Law School and can be contacted at stephen.j.dietz@gmail.com. trade deals, could make or break any negotiation to which the United States was a party. The timing of the deal was in no small measure dictated by the United States' electoral cycle (which leaves an unhelpfully narrow window between campaigns), as was the conclusion of the Trans-Pacific Partnership negotiations.

Congressional dysfunction also has significant knock-on effects abroad. China's establishment of the Asian Infrastructure Investment Bank, a regional development bank similar to the World Bank, was seen by many as a response to Congress' failure for over five years to approve reallocation of voting rights in the International Monetary Fund to properly reflect the size of China's economy. One could find any number of such instances-the International Trade Organization after World War II, or the League of Nations after World War I-but the reality is self-evident: in international affairs, Congress is an indispensable player that must be dealt with independently of the president and the administration. So I joined the CFP in search of insight into what, if anything, makes Congress tick.

I was not disappointed.

The first three months of the program was a boot camp of sorts, in which a who's who of Capitol Hill players schooled my fellow fellows and me on the policy, procedure, and politics of Congress. We began with a course on how Congress handles foreign policy and defense issues at Johns Hopkins School for Advanced International Studies, taught from a practical perspective by Charlie Stevenson, a former staffer who for decades served senators including vice president Joe Biden. We then moved to a daily regimen of panel discussions: legislative and budget process with the Congressional Research Service (to whom staffers turn when a point of congressional arcana needs clarification); press relations with C-SPAN, National Public Radio, and CQ-Roll Call; the function of think tanks with the Heritage Foundation and the Center for American Progress; and countless other experts that make up the ecology of the legislative branch.

The educational experience was enriched immeasurably by the diversity of views contributed by other fellows, many of whom were sent from executive agencies (State, Treasury, the intelligence community, and so forth) tasked with implementing the policies we were discussing. We had an especially strong contingent of health policy experts, ranging from hospital administration and management to aging and disability specialists, who could press speakers in great depth on some of the United States' most pressing public policy issues: health insurance, pharmaceutical prices, social security for pensioners and veterans, and so on.

Armed with this knowledge, we were let loose to find a placement with a senator or representative on the Hill, which was an education in itself. I met with dozens of current and former staffers to narrow down the offices that could offer the kinds of experiences I was looking for, where I could make a real contribution, and that 
had physical space for me to sit (you would be surprised how many did not...). I was fortunate to be offered a position on the foreign policy, defense, and homeland security team in the office of senator Bob Casey (D-PA). This proved to be an ideal vantage point: Senator Casey was generous with his time and appreciative of my advice, and his staff was extraordinarily experienced, welcoming, and, above all, patient. I was treated as a substantive member of the team and my responsibilities reflected this.

Working in an office was where the CFP's rubber hit the road for me. Like all fellows, I had to get across a startling array of issues, ranging from the Iran nuclear deal to the Cuba rapprochement, from appropriations to counterterrorism strategy, from women's health and education abroad to the South China Sea, and everything in between. Simultaneously, I had to learn the tools of the Senate's trade, applying some of those lessons we learned in CFP Boot Camp. In the first weeks I drafted policy recommendations and briefs, reviewed legislation, and met with constituents to discuss their views on any number of issues. By the end of my fellowship in August, I had written speeches and floor statements, unpacked what the president's budget request would mean for policy in the coming fiscal year (more difficult than it sounds), and prepared, through research and dialogue with stakeholders and policy specialists (and with substantial help from my colleagues, of course), a significant piece of legislation for tabling.

It is in performing these kinds of tasks that one grapples with the forces that many claim hamstring Congress. Reconciling and responding to competing views among constituents, think tanks, and the administration requires latitude to change positions over time, of which voters are rarely forgiving. Similarly, compromising on legislation in order to get an outcome can be perceived as a sign of weakness. Naturally, when faced with the choice of recommending such a compromise, it seems like anything but.

So as not to get swept up in the process in Washington, DC and forget about Congress' reputation outside the Beltway, the CFP supports all fellows to spend a week in the district or state that their representative or senator represents. I spent my week driving anticlockwise around Pennsylvania, through Harrisburg, Philadelphia, Erie, and Pittsburgh (and everywhere in between), speaking with the people for whom we worked. This afforded me the opportunity to see firsthand the work legislators do to advocate for constituents in their dealings with executive branch agencies, as well as the contribution Pennsylvanians make to American foreign policy and national security. I visited military installations, the Army War College at Carlisle, and public research institutes developing methods to combat terrorism at home and abroad, all of which provided me with useful perspective.

Federal politics followed me when I left Senator Casey's office, in the spectacular guise of the 2016 election. The public discourse over issues such as income inequality, the crisis in Syria, or the Trans-Pacific Partnership left me wishing more electors had had the opportunity to take part in the CFP. The best representatives and senators do not legislate by ideology once they get into office. They must fight for outcomes in the hope of incremental change for the better (thus Congress' ignominious reputation). Expecting them to do otherwise-expecting a revolution in Washington, DC-is asking to be disappointed, whether it succeeds or fails.

One can take comfort, at least, in the fact that the CFP alumni numbers in the thousands, and they teach their perspective in universities and apply it in practice across the country and around the world. 